\title{
Calibration between eustatic estimates from backstripping and oxygen isotopic records for the Oligocene
}

\author{
Stephen F. Pekar Lamont-Doherty Earth Observatory of Columbia University, Palisades, New York 10964, USA \\ Nicholas Christie-Blick Department of Earth and Environmental Sciences and Lamont-Doherty Earth Observatory of Columbia \\ University, Palisades, New York 10964, USA \\ Michelle A. Kominz Department of Geosciences, Western Michigan University, Kalamazoo, Michigan 49008, USA \\ Kenneth G. Miller Department of Geological Sciences, Wright Labs, Rutgers University, Piscataway, New Jersey 08854, USA
}

\begin{abstract}
Eustatic estimates from the backstripping of Oligocene sections are compared quantitatively with $\delta^{\mathbf{1 8}} \mathrm{O}$ data. Each of the nine Oligocene $\delta^{18} O$ events (maxima) identified in previous studies correlates with a stratigraphically determined sea-level lowstand. Oxygen isotopic records from planktonic foraminifers from western equatorial Atlantic Ocean Drilling Program (ODP) Site 929 indicate an isotopic increase of $0.16 \%$ per $10 \mathrm{~m}$ decrease in the depth of the ocean (apparent sea level, ASL). Amplitudes of ASL change also correlate with moderate- and high-resolution benthic foraminiferal $\delta^{18} \mathrm{O}$ records from ODP Sites 803 (western tropical Pacific) and 929 and from Deep Sea Drilling Project (DSDP) Site 522 (South Atlantic Ocean), with an isotopic change of $0.22 \%$ per 10 $\mathrm{m}$ of ASL change $\left(r^{2}=0.807\right.$ and 0.960 , respectively), and with records from ODP Site 689 (Southern Ocean; $0.13 \%$ per $10 \mathrm{~m}$ of ASL change; $\left.r^{2}=0.704\right)$. This correlation suggests that Southern Ocean deep-water temperature changes were smaller than tropical sea-surface temperature changes between million year-scale glacials and interglacials. It also suggests that the deep-sea Southern Ocean records may provide the best means to calibrate sea level to oxygen isotopes.
\end{abstract}

Keywords: eustasy, apparent sea level, oxygen isotopes, Oligocene, New Jersey, calibration.

\section{INTRODUCTION}

Published estimates of pre-Quaternary eustatic amplitudes have been obtained primarily from (1) an assessment of stratal geometry at passive continental margins and other marine basins (seismic and sequence stratigraphy; e.g., Haq et al., 1987), and (2) oxygen isotopic data, assuming the Pleistocene $\delta^{18} \mathrm{O}$ calibration of $0.11 \%$ increase per $10 \mathrm{~m}$ sea-level fall for implied ice-volume-related changes in sea level (e.g., Miller et al., 1991; Abreu and Anderson, 1998). The main difficulties with the sequence stratigraphic approach are the commonly unwarranted assumption of tectonic stability and the difficulty inherent in obtaining quantitative estimates of eustasy from inferred changes in coastal onlap (Christie-Blick et al., 1990). The main uncertainties with the isotopic approach are twofold. First, it does not reflect eustatic changes that are unrelated to changes in continental ice volume (e.g., tectonoeustasy). Second, it records both temperature $(0.22 \%$ increase for a $1{ }^{\circ} \mathrm{C}$ decrease) and ice-volume changes and, in the absence of rigorous independent constraints on eustatic amplitude, there has been no way to assess whether the Pleistocene isotopic-eustatic calibration is appropriate for the pre-Pleistocene. Studies using $\mathrm{Mg} / \mathrm{Ca}$ ratios have begun to provide estimates of bottom-water temperature, permitting the isotopic proxy for continental ice volume to be evaluated for the $\mathrm{Pa}$ leogene and Neogene with 500 k.y. resolution (e.g., Lear et al., 2000).

Recent studies of Oligocene strata at the New Jersey continental margin have yielded estimates of eustatic change during the early development of the late Cenozoic icehouse world (34.2-23.6 Ma) that are sufficiently precise with respect to both timing and amplitude to permit comparison with the deep-sea $\delta^{18} \mathrm{O}$ record. The principal in- novations in this research were (1) to make use of Sr isotope chemostratigraphy within an integrated chronostratigraphic framework to date a series of offlapping sequences with an absolute precision of \pm 0.3 to \pm 0.7 m.y. and relative precision as good as \pm 0.1 m.y. (see Pekar et al., 2000; Kominz and Pekar, 2001, for a discussion of dating and age uncertainties); (2) to quantify paleowater-depth changes in a transect of boreholes using a combination of benthic foraminiferal biofacies analysis and two-dimensional backstripping (Pekar and Kominz, 2001); and (3) to estimate eustatic amplitudes using two-dimensional backstripping (Kominz and Pekar, 2001). This paper presents the first calibration for the Oligocene of sea-level amplitudes derived from backstripping with $\delta^{18} \mathrm{O}$ changes in benthic and planktonic foraminifers. This result permits ice-volume effects (i.e., sea-level changes) to be removed from benthic foraminiferal isotopic records to solve for changes in water temperature associated with the same isotopic events at Southern Ocean, mid-latitude, and equatorial sites and from western equatorial planktonic foraminiferal $\delta^{18} \mathrm{O}$ records.

\section{EUSTASY VERSUS APPARENT SEA-LEVEL CHANGE}

In comparing stratigraphic and oxygen isotope records, the distinction between eustasy and apparent sea-level (ASL) change (defined here) is useful. Eustasy is the change in sea level with respect to a reference frame that is fixed relative to the center of Earth, and is due to variations in the volume of Earth's ocean water and in the hypsometry of the ocean basins. As sea level either rises or falls eustatically, flooded portions of the crust undergo water loading or unloading, so that observed fluctuations in water depth relative to the ocean floor (here termed apparent sea-level changes) exceed the eustatic changes that were responsible (by a factor of $\sim 1.48$; Kominz and Pekar, 2001). Changes in ASL are solely of eustatic origin, but they differ in amplitude because their reference frame is different. The concept of ASL change also differs from that of water-depth change at passive continental margins and other sedimentary basins, because water depth at such locations is influenced by sediment accumulation and by subsidence unrelated to changes in water loading. The concept of relative sea-level change is avoided herein because, as widely used in the stratigraphic literature, it implicitly includes the effects of sediment loading (e.g., Posamentier et al., 1988).

The sea-level changes observed at small islands in the ocean are ASL changes because the crust that underlies such islands is regionally loaded by water. The ice-volume-related changes in sea level obtained from such locations for calibration against oxygen isotope records (e.g., Barbados; Fairbanks, 1989) need to be multiplied by 0.68 to obtain eustatic changes. (Full isostatic compensation is assumed for time scales $>10^{4} \mathrm{yr}$ on the basis of Holocene patterns of continental postglacial rebound. The degree to which oceanic islands respond to water loading and unloading at shorter time scales is unclear.) Similarly, eustatic estimates derived from backstripping the Oligocene of the New Jersey margin must be multiplied by 1.48 to obtain ASL changes for comparison with ice-volume variations and global oxygen isotope records. 
Figure 1. Comparison of deep-sea oxygen isotopic records and events with sequence development and inferred apparent sea level (ASL) and eustatic changes at New Jersey margin for Oligocene. A: ML and 01-06 are sequences (from Pekar et al., 2000). Shaded boxes indicate time represented by sediments; diagonal lines represent age uncertainty; curved lines represent hiatuses. $B$ and C: Apparent sea level (upper scale) and eustasy (lower scale). Curve shown in $\mathrm{C}$ is detrended for long-term sea-level lowering during Oligocene. Bold line is best estimate for shortterm sea-level change; uncertainty is indicated by gray shading (from Kominz and Pekar, 2001).

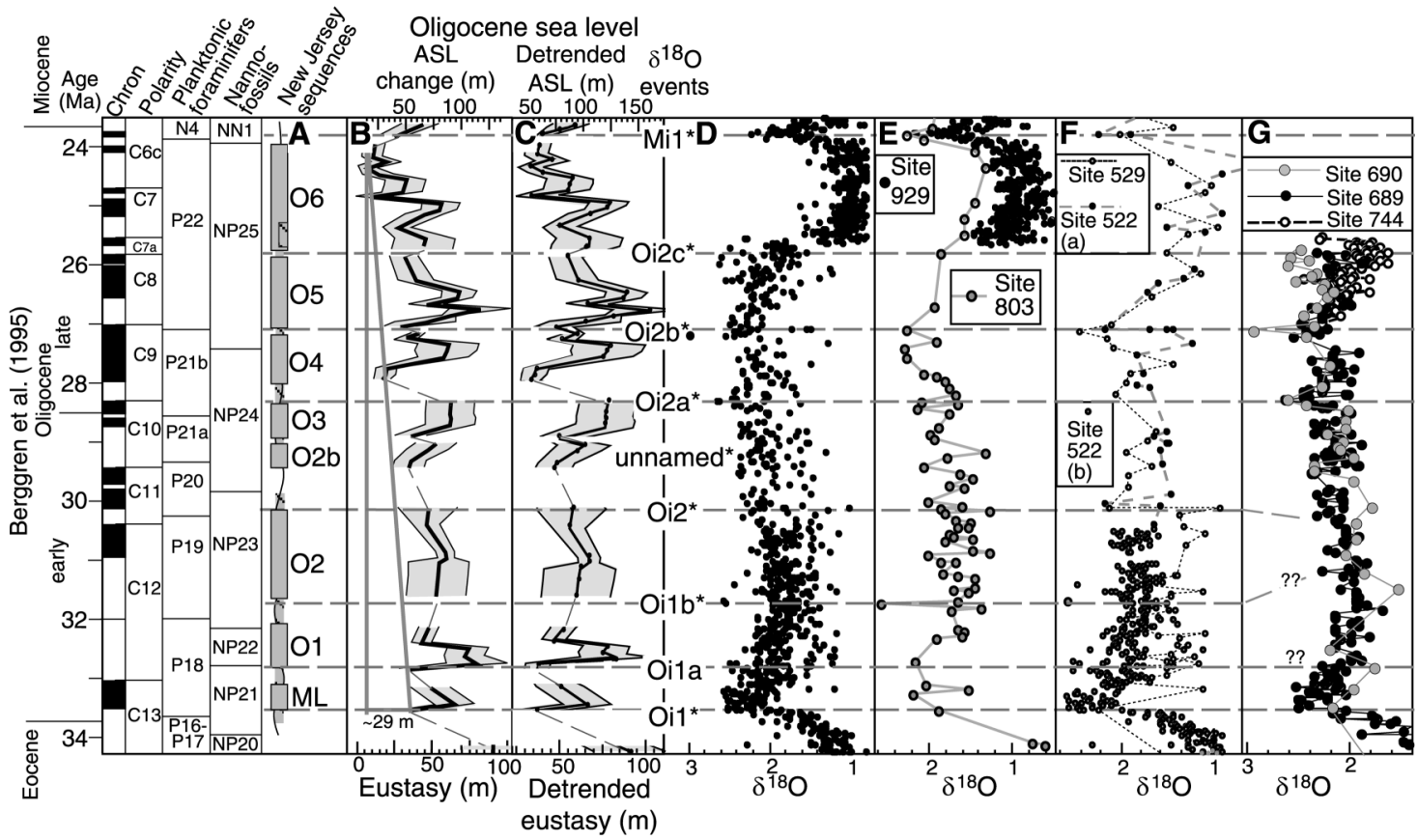

Last eustatic maximum for Eocene is set at $91 \mathrm{~m}$, and is not tied to present-day sea level. Detrended estimates of eustatic lows at beginning (33.5 Ma), middle $(28.0 \mathrm{Ma})$, and end of Oligocene (23.9 Ma) are comparable. D: Isotopic events ( $\delta^{18} \mathrm{O}$ maxima, from Miller et al., 1991 ; Pekar and Miller, 1996) and composite $\delta^{18} \mathrm{O}$ record from Deep Sea Drilling Project (DSDP) and Ocean Drilling Program (ODP) sites shown in E, $F$, and G. Each oxygen isotopic event corresponds with major sea-level fall (dashed gray lines). Asterisks indicate events recognized also by Abreu and Anderson (1998). Oxygen isotope events represent inferred ice growth and were defined on basis of substantial global increases $\left(>0.5 \%\right.$ ) in benthic oxygen isotopic values and coeval shifts in western equatorial planktonic $\delta^{18} \mathrm{O}$ records. E: Tropical ODP Sites 803 (Barrera et al., 1993) and 929 (Zachos et al., 1997). F: Mid-latitude DSDP Site 522, with moderately low-resolution record (a) from Miller et al. (1987) and high-resolution record (b) from Zachos et al. (1996), and DSDP Site 529 (Miller et al., 1991). G: Southern Ocean ODP Sites 689 (Thomas et al., 1995), 744 (Zachos et al., 1996), and 690 (Kennett and Stott, 1990). Abrupt change in $\delta^{18} \mathrm{O}$ values at $25.5 \mathrm{Ma}$ in composite record (D) reflects change in source of data, mainly from Site 929 above and mid-latitude and Southern Ocean sites below. Offset between Southern Ocean sites and Site 929 is $\sim 1.0 \%$, and is probably due to temperature. Additional peaks evident in these records have not been recognized globally in benthic foraminiferal $\delta^{18} \mathrm{O}$ data (i.e., at more than one site; e.g., Miller et al., 1991), nor have they been identified in western tropical planktonic $\delta^{18} \mathrm{O}$ data. These peaks may represent local variability (i.e., bottom-water temperature changes) or perhaps higher frequency events not recognized previously. In low- to moderate-resolution isotope records (Site 522 above 30.4 Ma, and Sites 529 , 690, and 803) potential exists for aliasing of obliquity and precessional Milankovitch cycles. Berggren et al. (1995) time scale is used throughout.

\section{STRATIGRAPHIC RECORD OF OLIGOCENE EUSTASY COMPARED TO $\delta^{18} \mathrm{O}$ RECORDS}

The stratigraphic record of Oligocene eustasy at the New Jersey margin is defined at 61 control points between $34.2 \mathrm{Ma}$ and 23.6 Ma (Fig. 1; Kominz and Pekar, 2001), with an average spacing between points of 174 k.y. and a range of 100-700 k.y. (The latter corresponds with a hiatus in available data between 30.1 and 29.4 Ma.) Uncertainties in eustatic level shown in Figure 1 reflect uncertainties in paleowater depth (from foraminiferal biofacies) and in the manner in which the sediments compacted during burial. The amplitude of eustatic oscillations in the Oligocene is estimated to range from 10 to $54 \mathrm{~m}$ (equivalent to ASL changes of 15 to $80 \mathrm{~m}$ ). These oscillations are superimposed on a long-term eustatic fall through the Oligocene of nearly $30 \mathrm{~m}$, a trend that is thought to be related to tectonoeustatic changes (e.g., average age of oceanic lithosphere, Kominz, 1984; thermal subsidence of broad regions of crust produced by Cretaceous age magmatism in the Pacific, Schlanger et al., 1981).

Comparison between the stratigraphically derived eustatic record from the Oligocene of the New Jersey margin and deep-sea $\delta^{18} \mathrm{O}$ data confirms the correspondence of prominent glacial-eustatic lowerings and $\delta^{18} \mathrm{O}$ increases at the million year time scale (i.e., $\delta^{18} \mathrm{O}$ events; Miller et al., 1991; Pekar and Miller, 1996; Zachos et al., 1996, 1997). Although 40 k.y. and 400 k.y. Milankovitch cycles are a pervasive feature of the isotopic data, as in the Pliocene-Pleistocene, they are subordinate to the named isotopic events (Paul et al., 2000). The nine eustatic falls observed at the New Jersey margin (Fig. 1) correspond closely with the $\delta^{18} \mathrm{O}$ events of Miller et al. (1991), Pekar and Miller (1996), and Abreu and Anderson (1998). These events are characterized by large $\delta^{18} \mathrm{O}$ increases $\left(>0.5 \%\right.$ ), by high maximum $\delta^{18} \mathrm{O}$ values $(>2.0 \%$ ) , and by covariance between benthic and tropical planktonic $\delta^{18} \mathrm{O}$ records (Miller et al., 1991). Taken together, these data indicate the presence of continental ice sheets (e.g., Miller et al., 1991). In addition, between 29.9 and $28.5 \mathrm{Ma}, \delta^{18} \mathrm{O}$ values are consistently high $(>1.8 \%$ o), and there are several peaks above $2.2 \%$ (Fig. 1), suggesting possible additional minor sea-level oscillations (e.g., at 29.5 Ma as well as ca. 29.0 Ma).

The overall shapes of the eustatic and isotopic records appear to track closely between 34 and $25 \mathrm{Ma}$. However, ca. $25 \mathrm{Ma}$, a rapid lowering and rise in the sea-level record is observed without a corresponding significant increase in $\delta^{18} \mathrm{O}$ values. Divergence between the two records may be due to the temperature dependence of the isotopic data or to uncertainties in correlation. For example, between 25.5 and 23.9 $\mathrm{Ma}$, the sea-level record was dated exclusively with reference to $\mathrm{Sr}$ isotopic values, with age uncertainties ranging from \pm 0.6 to \pm 1.0 m.y. (at the 95\% confidence level, Miller et al., 1998). Further studies are needed to address details for these time intervals. However, the general agreement between isotopic and stratigraphic records suggests that eustatic estimates from the New Jersey margin are robust, and that simplifying assumptions about the pattern of tectonic subsidence are reasonable.

Correlation between deep-sea $\delta^{18} \mathrm{O}$ amplitudes and ASL amplitudes is good to excellent for moderate- and high-resolution records at 
TABLE 1. COMPARISON BETWEEN EUSTATIC AND APPARENT SEA-LEVEL AMPLITUDES FROM NEW JERSEY AND OXYGEN ISOTOPE AMPLITUDES FROM DSDP and ODP SITES

\begin{tabular}{|c|c|c|c|c|c|c|c|c|c|c|c|c|}
\hline \multicolumn{5}{|c|}{ New Jersey } & \multicolumn{2}{|c|}{ Site 689} & \multicolumn{2}{|c|}{ Site 522} & \multicolumn{2}{|c|}{ Site 929} & \multicolumn{2}{|c|}{ Site 803} \\
\hline $\begin{array}{l}\delta^{18} \mathrm{O} \\
\text { event }\end{array}$ & $\begin{array}{l}\text { Age } \\
(\mathrm{Ma})\end{array}$ & $\begin{array}{l}\text { Eustatic } \\
\text { lowstand } \\
\text { (m) }\end{array}$ & $\begin{array}{c}\text { Eustatic } \\
\text { change } \\
\text { (m) }\end{array}$ & $\begin{array}{c}\text { ASL } \\
\text { change } \\
(\mathrm{m})\end{array}$ & $\begin{array}{c}\text { Max. } \\
\text { value } \\
(\% \circ)\end{array}$ & $\begin{array}{c}\text { Amplitude } \\
(\% \circ)^{*}\end{array}$ & $\begin{array}{c}\text { Max. } \\
\text { value } \\
(\% \circ)\end{array}$ & $\begin{array}{c}\text { Amplitude } \\
(\% \circ)^{*}\end{array}$ & $\begin{array}{c}\text { Max. } \\
\text { value } \\
(\% \circ)\end{array}$ & $\begin{array}{c}\text { Amplitude } \\
(\% \circ)^{*}\end{array}$ & $\begin{array}{c}\text { Max. } \\
\text { value } \\
(\% \circ)\end{array}$ & $\begin{array}{c}\text { Amplitude } \\
(\% \circ)^{*}\end{array}$ \\
\hline $\begin{array}{l}\text { Mi1 } \\
\text { Oi2c }\end{array}$ & $\begin{array}{l}23.8 \\
25.8\end{array}$ & $\begin{array}{l}34 \\
54\end{array}$ & $\begin{array}{l}38 \\
36\end{array}$ & $\begin{array}{l}56 \\
53\end{array}$ & \multicolumn{4}{|c|}{ uncertain $^{\dagger}$} & 2.2 & 1.3 & 2.2 & uncertain $^{\dagger}$ \\
\hline $\begin{array}{l}\text { Oi2b } \\
\text { Oi2a }\end{array}$ & $\begin{array}{l}27.1 \\
28.3\end{array}$ & $\begin{array}{l}48 \\
34\end{array}$ & $\begin{array}{l}32 \\
45\end{array}$ & $\begin{array}{l}47 \\
67\end{array}$ & $\begin{array}{l}2.6 \\
2.7\end{array}$ & $\begin{array}{l}0.7 \\
0.8\end{array}$ & 2.2 & $\operatorname{rtain}^{+}{ }^{0.9}$ & & & 2.3 & ertain $^{+}$ \\
\hline unnamed & 29.1 & 50 & 10 & 15 & 2.4 & 0.3 & \multicolumn{2}{|c|}{$\begin{array}{l}\text { uncertain }^{\dagger} \\
\text { uncertain }^{\dagger}\end{array}$} & & & \multicolumn{2}{|c|}{$\begin{array}{l}\text { uncertain }^{\dagger} \\
\text { uncertain }^{\dagger}\end{array}$} \\
\hline $\begin{array}{l}\text { Oi2 } \\
\text { Oi1b } \\
\text { Oi1a } \\
\text { Oi1 }\end{array}$ & $\begin{array}{l}30.1 \\
31.7 \\
32.8 \\
33.5\end{array}$ & $\begin{array}{l}47 \\
47 \\
37 \\
37\end{array}$ & $\begin{array}{l}21 \\
36 \\
29 \\
54\end{array}$ & $\begin{array}{l}31 \\
53 \\
43 \\
80\end{array}$ & $\begin{array}{l}2.4 \\
2.3 \\
2.5 \\
2.5\end{array}$ & $\begin{array}{l}0.5 \\
0.4 \\
0.5 \\
1.3\end{array}$ & $\begin{array}{l}2.2 \\
2.6 \\
2.5 \\
2.4\end{array}$ & $\begin{array}{l}0.7 \\
1.0 \\
0.8 \\
1.7\end{array}$ & & & $\begin{array}{l}2.0 \\
2.6 \\
2.1 \\
2.2\end{array}$ & $\begin{array}{l}0.6 \\
1.2 \\
0.6 \\
1.6\end{array}$ \\
\hline
\end{tabular}

Note: ASL is apparent sea level.

* Oxygen isotope amplitudes are difference between maximum value of $\delta^{18} \mathrm{O}$ event and preceding minimum $\delta^{18} \mathrm{O}$ value.

† Uncertain owing to low resolution.

$\S$ Age of maximum $\delta^{18} \mathrm{O}$ values.

western tropical Pacific and Atlantic Ocean Sites 803 and $929\left(r^{2}=\right.$ 0.807), mid-latitude Site $522\left(r^{2}=0.960\right)$, and Southern Ocean Site $689\left(r^{2}=0.704\right)$ (Table 1; Fig. 2). This correlation suggests that although benthic foraminiferal records are assumed to contain a significant bottom-water temperature signal, lowering of temperature results in a nearly linear increase in ice-volume estimates. The benthic foraminiferal $\delta^{18} \mathrm{O}$ change per $10 \mathrm{~m}$ of ASL change ranges from $0.13 \%$ o at Southern Ocean Site 689 to $0.22 \%$ at mid-latitude and equatorial Sites 522, 803, and 929 (Fig. 2).

High-resolution planktonic foraminiferal $\delta^{18} \mathrm{O}$ records of western equatorial Atlantic Site 929 (Paul et al., 2000) encompass one of the largest eustatic lowerings identified by Kominz and Pekar (2001), i.e., the $38 \mathrm{~m}$ lowering at the Oligocene-Miocene boundary $(56 \pm 12 \mathrm{~m}$ of ASL change). A $\delta^{18} \mathrm{O}$ increase of $0.88 \%$ and a $56 \mathrm{~m}$ ASL provide a calibration of $0.16 \%$ per $10 \mathrm{~m}$ of ASL lowering across this boundary.

A moderately high resolution $\mathrm{Mg} / \mathrm{Ca}$ ratio record combined with $\delta^{18} \mathrm{O}$ records from deep-sea benthic foraminifers across the Oil event suggests that ice volume increased from $\sim 2 \%$ of the full Pleistocene value (both hemispheres) to $\sim 38 \%$ (Lear et al., 2000). Assuming a

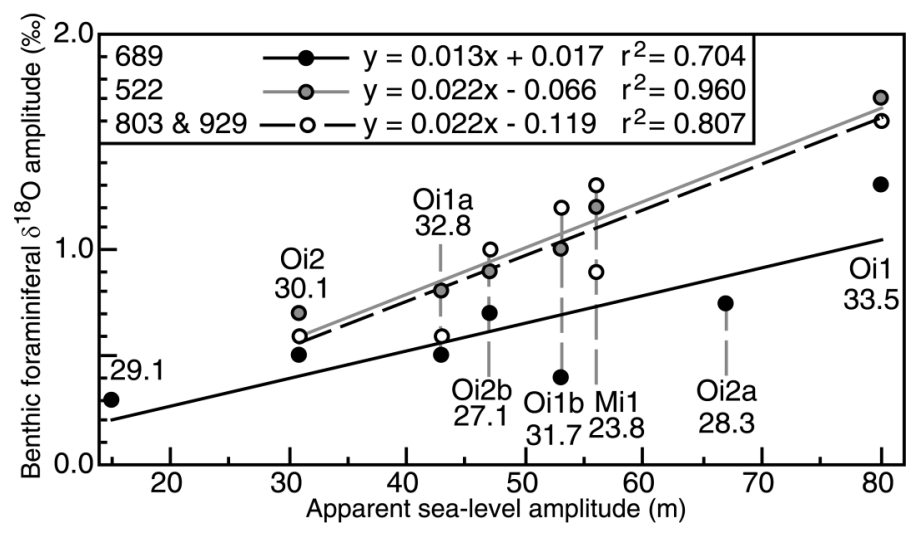

Figure 2. Benthic foraminiferal oxygen isotope amplitudes from high-resolution records from Deep Sea Drilling Project Site 522 (Zachos et al., 1996; 9 k.y. resolution), and Ocean Drilling Program (ODP) Sites 689 (Thomas et al., 1995; 40 k.y. resolution) and 929 (Zachos et al., 1997), and moderately high resolution records from ODP Site 803 (Barrera et al., 1993) are compared to detrended apparent sea-level amplitudes. Oxygen isotope events and their ages are shown. Oxygen isotope amplitudes are difference between maximum value of $\delta^{18} \mathrm{O}$ event and preceding minimum (or average minimum) $\delta^{18} \mathrm{O}$ values. Linear regression for western equatorial Site 803 includes one data point from Site 929 . Sea-level amplitudes represent difference between sea-level minimum and preceding sea-level maximum. total ice budget at the Last Glacial Maximum (LGM) equivalent to 194 $\mathrm{m}$ of ASL change (121 m from Fairbanks, 1989; plus $73 \mathrm{~m}$ stored in ice today), the sea-level change during the Oil event is estimated as $48 \mathrm{~m}$ eustatic or $70 \mathrm{~m}$ ASL. This is consistent with our eustatic estimate of $54 \pm 10 \mathrm{~m}$ for the earliest Oligocene fall $(80 \pm 15 \mathrm{~m}$ of ASL change).

\section{DISCUSSION AND CONCLUSIONS}

The calibration of $0.13 \%$ per $10 \mathrm{~m}$ ASL from Southern Ocean Site 689 is the lowest of this study and represents the minimum value for calibrating sea level to $\delta^{18} \mathrm{O}$ values. This calibration would account for $1.04 \%$ of the $1.3 \%$ change observed for the Oi1 event $(33.5 \mathrm{Ma})$ at Site 689. This calibration is further restricted by the results of Lear et al. (2000) that suggest that deep-water temperatures changed by no more than $1{ }^{\circ} \mathrm{C}$ for the Oil event. A $1{ }^{\circ} \mathrm{C}$ change would account for the remainder of the isotopic excursion. The maximum uncertainties in apparent sea-level amplitudes for the Oil event and the possible variability in deep-water temperature between million year-scale glacial and interglacial intervals result in a calibration range of $0.10 \%$ o $-0.13 \%$ o per $10 \mathrm{~m}$ ASL change for the Oligocene.

The lack of significant temperature change inferred from the Southern Ocean records implies that the rapid ice accumulation and the subsequent ice-volume changes during the Oligocene occurred without a significant decrease in source-water temperatures (i.e., polar surface waters). The lack of decreased temperatures of surface polar waters suggests that another mechanism, such as increased moisture for snow precipitation on Antarctica, may have led to ice-volume changes in Antarctica during the Oligocene. We hypothesize that the opening of the oceanic gateway between Australia and Antarctica may have increased moisture to Antarctica, resulting in higher precipitation over the Antarctic continent.

The mid-latitude to equatorial calibration of $0.22 \%$ per $10 \mathrm{~m} \mathrm{ASL}$ exceeds the Southern Ocean calibration, and indicates significant bottomwater temperature changes between glacial and interglacial intervals in these regions. For example, a change from $0.09 \%$ o to $0.12 \%$ o per $10 \mathrm{~m}$ (using the calibration range from $0.10 \%$ o to $0.13 \%$ o per $10 \mathrm{~m}$ from the Southern Ocean site) would be due to non-ice-volume changes at these sites. If these changes were due to temperature alone, then a $0.41-0.54$ ${ }^{\circ} \mathrm{C}$ change would be implied for each $10 \mathrm{~m}$ of ASL change for bottom waters and $41 \%-54 \%$ of the isotopic signal was due to temperature. These results represent a minimum value due to uncertainties in the temperature signal at Site 689 . In contrast, $25 \%-33 \%$ of the isotopic signal in Pleistocene deep-sea records is due to temperature change (Fairbanks and Matthews, 1978), suggesting that mid- to low-latitude deep waters varied more between million year-scale glacials and in- 
terglacials during the Oligocene than the thousand year-scale glacials and interglacials of the Pleistocene. Because Southern Ocean deep waters did not cool significantly during glacial periods (this study and Lear et al., 2000), non-Southern Ocean deep waters may have been cooled through increased flux of proto-Antarctic Bottom Water (as suggested by Miller, 1992).

The calibration of $\delta^{18} \mathrm{O}$ records from planktonic foraminifers from western equatorial sites of $0.16 \%$ per $10 \mathrm{~m}$ of ASL change is also higher than the calibration for the Southern Ocean Site 689 (0.13\%o per $10 \mathrm{~m})$. These results are similar to water-temperature changes inferred from records from the LGM to present, in which tropical seasurface temperatures (SSTs) changed by as much as $5{ }^{\circ} \mathrm{C}$ (Guilderson et al., 1994), while Southern Ocean deep-sea temperatures changed $<2$ ${ }^{\circ} \mathrm{C}$ (Birchfield, 1987). These data suggest that during the Paleogene, western tropical sea-surface temperatures may have varied more than deep-sea temperatures in the Southern Ocean between million yearscale glacial and interglacial times and that the fluctuations were greater than previously thought (Prentice and Matthews, 1991).

Our sea level/ $/ \delta^{18} \mathrm{O}$ calibration also has implications for continental ice-sheet development in the Oligocene. The calibration range of $0.10 \%$ o $-0.13 \%$ is similar to the late Pleistocene calibration by Fairbanks and Matthews (1978), and it implies an isotopic composition of Oligocene ice in Antarctica between $-40 \%$ and $-48 \%$, a range that is similar to isotopic values for the Greenland ice sheet at the LGM (Grootes et al., 1993). These nearly identical isotopic values are surprising. We infer the processes controlling moisture transport to ice sheets at mid-latitudes $\left(50^{\circ}-70^{\circ}\right)$ during late Pleistocene glacial intervals may have been similar to those operative at high latitudes $\left(70^{\circ}-\right.$ $90^{\circ}$ ) during the Oligocene.

\section{ACKNOWLEDGMENTS}

This research was supported by National Science Foundation (NSF) grants OCE-99-11121 to N. Christie-Blick and S.F. Pekar; EAR-94-17108, EAR-9708664, and EAR-99-09179 to K.G. Miller; EAR-95-06572, HRD-96-26177, and EAR-98-14025 to M.A. Kominz, and by the New Jersey Geological Survey. Cores were obtained by the New Jersey Coastal Plain Drilling Project (Ocean Drilling Program Legs 150X and 174AX), supported by the NSF Continental Dynamics and Ocean Drilling Programs and the New Jersey Geological Survey. We thank J.D. Wright for discussions and assistance, E. Thomas for isotopic data from Site 689, and D. Sahagian, T. Bralower, and an anonymous reviewer for their insightful comments. Lamont-Doherty Earth Observatory Contribution 6350

\section{REFERENCES CITED}

Abreu, V.S., and Anderson, J.B., 1998, Glacial eustasy during the Cenozoic: Sequence stratigraphic implications: American Association of Petroleum Geologists Bulletin, v. 82, p. 1385-1400.

Barrera, E., Baldauf, J., and Lohmann, K.C, 1993, Strontium isotope and benthic foraminifer stable isotopic results from Oligocene sediments at Site 803, in Berger, W.H., et al., Proceedings of the Ocean Drilling Program, Scientific results, Leg 130: College Station, Texas, Ocean Drilling Program, p. 269-279.

Berggren, W.A., Kent, D.V., Swisher, C.C., III, and Aubry, M.-P., 1995, A revised Cenozoic geochronology and chronostratigraphy, in Berggren, W.A., et al., eds., Geochronology, time scales and global stratigraphic correlation: SEPM (Society for Sedimentary Geology) Special Publication 54, p. 129-212.

Birchfield, E.G., 1987, Changes in deep-ocean water $\delta^{18} \mathrm{O}$ and temperature from the Last Glacial Maximum to the present: Paleoceanography, v. 2, p. 431-442.

Christie-Blick, N., Mountain, G.S., and Miller, K.G., 1990, Seismic stratigraphic record of sea-level change, in Sea-level change: Studies in geophysics: Washington, D.C., National Academy Press, p. 116-140.

Fairbanks, R.G., 1989, Glacio-eustatic record 0-16000 years before present: Influence of glacial rates on Younger Dryas event and deep ocean circulation: Nature, v. 342, p. 637-642.

Fairbanks, R.G., and Matthews, R.K., 1978, The marine oxygen isotopic record in Pleistocene coral, Barbados, West Indies: Quaternary Research, v. 10, p. 181-196.

Grootes, P.M., Stulver, M., White, J.W.C., Johnsen, S., and Jouzel, J., 1993,
Comparison of oxygen isotope records from the GISP2 and GRIP Greenland ice cores: Nature, v. 366, p. 552-554.

Guilderson, T.P., Fairbanks, R.G., and Rubenstone, J.L., 1994, Tropical temperature variations since 20000 years ago: Modulating interhemispheric climate change: Science, v. 263, p. 663-665.

Haq, B.U., Hardenbol, J., and Vail, P.R., 1987, Chronology of fluctuating sea levels since the Triassic: Science, v. 235, p. 1156-1167.

Kennett, J.P., and Stott, L.D., 1990, Proteus and Proto-Oceanus: Ancestral Paleogene oceans as revealed from antarctic stable isotopic results, in Barker, P.F., Kennett, J.P., et al., eds., ODP Leg 113. Proceedings of the Ocean Drilling Program, Scientific results, Volume 113B: College Station, Texas, Ocean Drilling Program, p. 865-880.

Kominz, M.A., 1984, Oceanic ridge volumes and sea level change-An error analysis, in Schlee, J., ed., Interregional unconformities and hydrocarbon accumulation: American Association of Petroleum Geologists Memoir 36, p. $109-127$.

Kominz, M.A., and Pekar, S.F., 2001, Oligocene eustasy from two-dimensional sequence stratigraphic backstripping: Geological Society of America Bulletin, v. 113, p. 291-304.

Lear, C.H., Elderfield, H., and Wilson, P.A., 2000, Cenozoic deep-sea temperature and global ice volumes from $\mathrm{Mg} / \mathrm{Ca}$ in benthic foraminiferal calcite: Science, v. 287, p. 269-272.

Miller, K.G., 1992, Middle Eocene to Oligocene stable isotopes, climate, and deep-water history: The terminal Eocene event?, in Prothero, D., and Berggren, W.A., eds., Eocene-Oligocene climatic and biotic evolution: Princeton, New Jersey, Princeton University Press, p. 160-177.

Miller, K.G., Fairbanks, R.G., and Mountain, G.S., 1987, Tertiary oxygen isotope synthesis, sea-level history, and continental margin erosion: Paleoceanography, v. 2, p. 1-19.

Miller, K.G., Wright, J.D., and Fairbanks, R.G., 1991, Unlocking the ice house: Oligocene-Miocene oxygen isotopes, eustasy, and margin erosion: Journal of Geophysical Research, v. 96, p. 6,829-6,848.

Miller, K.G., Mountain, G.S., Browning, J.V., Kominz, M., Sugarman, P.J., Christie-Blick, N., Katz, M.E., and Wright, J.D., 1998, Cenozoic global sea level, sequences, and the New Jersey Transect: Results from coastal plain and continental slope drilling: Reviews of Geophysics, v. 36, p. 569-601.

Paul, H.A., Zachos, J.C., Flower, B.P., and Tripati, A., 2000, Orbitally induced and geochemical variability across the Oligocene/Miocene boundary: $\mathrm{Pa}-$ leoceanography, v. 15, p. 471-585.

Pekar, S.F., and Kominz, M.A., 2001, Two-dimensional paleoslope modeling: A new method for estimating water depths for benthic foraminiferal biofacies and paleo shelf margins: Journal of Sedimentary Research, v. 71, p. 608-620.

Pekar, S.F., and Miller, K.G., 1996, New Jersey Oligocene "Icehouse" sequences (ODP Leg 150X) correlated with global $\delta^{18} \mathrm{O}$ and Exxon eustatic records: Geology, v. 24, p. 567-570.

Pekar, S.F., Miller, K.G., and Kominz, M.A., 2000, Reconstructing the stratal geometry of latest Eocene to Oligocene sequences in New Jersey: Resolving a patchwork distribution into a clear pattern of progradation: Sedimentary Geology, v. 134, p. 93-109.

Posamentier, H.W., Jervey, M.T., and Vail, P.R., 1988, Eustatic controls on clastic deposition I-Conceptual framework, in Wilgus, C.K., et al., eds., Sealevel changes: An integrated approach: Society of Economic Paleontologists and Mineralogists Special Publication 42, p. 109-124.

Prentice, M.L., and Matthews, R.K., 1991, Tertiary ice sheet dynamics: The snow gun hypothesis: Journal of Geophysical Research, v. 96, p. 6811-6827.

Schlanger, S.O., Jenkyns, H.C., and Premoli-Silva, I., 1981, Volcanism and vertical tectonics in the Pacific Basin related to global Cretaceous transgressions: Earth and Planetary Science Letters, v. 52, p. 435-449.

Thomas, E., Zahn, R., and Diester-Hauss, L., 1995, The Eocene-Oligocene transition at high latitudes: Benthic foraminifera, sediments and stable isotopes: Eos (Transactions, American Geophysical union), v. 76, supplement, p. S187

Zachos, J.C., Quinn, T.M., and Salamy, S., 1996, High resolution (104 yr) deepsea foraminiferal stable isotope records of the earliest Oligocene climate transition: Paleoceanography, v. 9, p. 353-387.

Zachos, J.C., Flower, B.P., and Paul, H., 1997, Orbitally paced climate oscillations across the Oligocene/Miocene boundary: Nature, v. 388, p. $567-570$.

Manuscript received March 15, 2002

Revised manuscript received June 17, 2002

Manuscript accepted June 20, 2002

Printed in USA 